\title{
CONHECIMENTO, CIÊNCIA E VERDADE EM SANTO AGOSTINHO
}

\author{
Marcos Roberto Nunes Costa*
}

SINTESE - Toda antropologia agostiniana gira em torno do problema da busca da felicidade do homem, que só será alcançada em Deus - a verdade. Assim sendo, o problema do homem converte-se na busca da verdade. $\mathrm{Na}$ "filosofia cristã" agostiniana a fé é condição primeira do conhecimento da verdade, entretanto, dá-se capital importância à razão no processo do conhecimento humano que está dividido em três niveis: conhecimento sensivel, sensação e razão ou ciência. Além disso há um quarto grau - a verdade (Deus), que foge ao alcance da razão humana. Essa só contemplamos mediante a ajuda da graça divina.

PALAVRAS-CHAVE - Agostinho, teoria do conhecimento, ciência.
ABSTRACT - The dominant problem of Augustine's anthropoiogy is the search for the human happiness, which will be reached only in God - the Truth. Therefore we can say that the problem of his anthropology is the search for truth. The faith is in Augustinian "Christian philosophy" the first condition to know the truth. But he also gives a great importance to the reason in the knowledge's process with its three levels: sensible knowledge, sensation and reason or science. There is yet another level - the truth (God), unattainable to human reason, which we only contemplate by means of the help of God's grace.

KEY WORDS - Augustine, theory of knowledge, science.

\section{Introdução}

Apesar de ser detentor de uma imensa produção literária, ${ }^{1}$ Agostinho é um pensador assistemático que fala sobre tudo em todo lugar. Até porque não estava preocupado em produzir um "sistema filosófico" como produto de mera especulação intelectual desligada da realidade, ou seja, Agostinho não era o que hoje chamamos de um intelectual de gabinete. Seus escritos, com raras exceções, são respostas a problemas reais, fruto do envolvimento com as grandes questões doutrinais de seu tempo, especialmente os embates com as principais heresias que ameaçavam a doutrina da Igreja (Maniqueísmo, Donatismo, Arianismo e Pelagianismo); ou são respostas às mais variadas questões (politico-sociais, espirituais, domésticas, etc.), que lhes eram solicitadas, em cartas, por seus diocesanos.

* Professor da UNICAP e Doutorando em Filosofia pela PUCRS.

1 RUBIO, Pedro. Toma e Lêll: síntese agostiniana. s. Trad. São Paulo: Loyola, 399 p. 398, nos diz que, na Coleção Latina de Escritores Cristãos (MIGNE), encontram-se mais de 150 títulos diferentes, sem contar as centenas de cartas, sermões e pequenos tratados.

\begin{tabular}{|l|l|l|l|l|l|}
\hline VERITAS & Porto Alegre & v. 43 & $\mathrm{n}^{\mathrm{0}} 3$ & Setembro 1998 & p. 483-496 \\
\hline
\end{tabular}


Isto dito, encontramos um sistema filosófico em Agostinho não de forma explícita, mas nas entrelinhas de seus escritos, o que não deixa de formar um corpo teórico coerente. Assim sendo, grande parte dos temas filosóficos a serem pesquisados neste pensador aparecem embutidos em outros temas correlatos, ou seja, de forma indireta.

O tema que nos propusemos pesquisar neste artigo não foge à regra. Ele não escreveu um tratado específico sobre o assunto, temos que buscá-lo em muitos de seus escritos, nomeadamente naqueles que tratam de temas como Deus, o homem, a filosofia, a sabedoria, o livre arbítrio, iluminação divina e outros.

Assim sendo, como metodologia de trabalho: começar nossas discussöes por outros estudos correlatos, mais especificamente o problema do homem, passando pelo problema de Deus, para nestes situarmos e apresentarmos o tema proposto.

\section{1 - O problema do homem: a busca da "verdadeira felicidade"}

Podemos dizer que toda a antropologia filosófica de Santo Agostinho gira em torno do problema da felicidade do homem e que esta se confunde com o problema do homem Agostinho; o problema de sua dispersão, inquietude e busca da felicidade: "Eu me havia convertido em um grande problema. Perguntava à minha alma por que estava triste e angustiado, mas nada sabia responder-me" (Conf. IV, 4). ${ }^{2}$ O centro de sua especulação filosófica coincide verdadeiramente com sua personalidade. Sua filosofia é uma interpretação da própria vida.

Em A Cidade de Deus, Agostinho afirma que nós todos, os homens, queremos ser felizes: "É pensamento unânime de todos quantos podem fazer uso da razão que todos os mortais querem ser felizes. Mas quem é feliz, como tornar-se feliz, eis o problema que a fraqueza humana propõe e provoca numerosas e intermináveis discussões [...]" (De Civ. Dei X, 1). "Esta constatação ele a põe na base e no início de todas as suas argumentações, em resposta às mais variadas interrogações ou situações [...]". ${ }^{3}$

Em uma de suas epístolas, ao aconselhar à rica viúva Proba sobre o que pedir em oração, Agostinho coloca que a busca da felicidade é algo imanente ao homem, fazendo, assim, parte da natureza humana; todos os homens, bons e maus, a desejam: "Todos os homens querem possuir vida feliz, pois mesmo os que vivem mal não viveriam desse modo, senão acreditassem que, assim, são, ou que podem vir a ser felizes. Que outra coisa te convém pedir senão o que bons e maus procuram adquirir, ainda que somente os bons consigam?"(Ep. 130 IV,9). ${ }^{4}$ Esse é o pro-

2 Para as obras do próprio Agostinho, usaremos, daqui para frente, as seguintes abreviaturas: Confessionum (As Confissōes) - "Conf."; De Civitate Dei (A Cidade de Deus) - "De Civ. Dei"; De Beata Vita (A Vida Feliz) - "De beat. Vita"; De Libero Arbitrio (O Livre Arbitrio) - "De Lib. Arb."; De Vera Religione (A Verdadeira Religião) - "De Vera Rel."; De Doctrina Christiana (A Doutrina Cristā) - De Doc. Christ."; De Trinitate (A Trindade) - "De trin."; Inarrationes in Psalmos (Cimentários aos Salmos) - "In Ps"; Solilóquia (Solilóquios) - "Sol".

3 RAMOS, Francisco Manfredo T. A Idéia de Estado na Doutrina Ético-Política de Santo Agostinho: um estudo do epistolário comparado com o "De Civitate Dei”. São Paulo: Loyola, 1984, 370 p. 48.

4 AGOSTINHO, Santo. Carta a Proba e a Juliana: direção espiritual. Trad. Nair de Assis Oliveira. São Paulo: Paulinas, 1987, 99 p. 24. Igualmente em A Trindade, Agostinho, servindo-se das palavras de Cicero, em o "Hortênsios", diz: 'Todos certamente queremos ser felizes"' (XII, 5,7) 
blema - a felicidade humana - que perpașsa toda produção literária de Agostinho, desde os primeiros diálogos filosóficos, passando pelas dezenas de obras filosóficoteológicas e centenas de cartas e sermões.

Já nos primeiros diálogos filosóficos. escritos no retiro de Cassicíaco, logo após sua conversão, a grande preocupação de Agostinho era responder às questões: Onde está a felicidade? Como e onde o homem pode ser feliz? Em A Vida Feliz, tentando responder a essas questões, depois de buscar e não encontrar, entre os bens materiais, um que possa trazer a verdadeira felicidade, uma vez que são todos mutáveis, concluí uma primeira parte do diálogo dizendo: "Por conseguinte, estamos convencidos de que, se alguém quiser ser feliz, deverá procurar um bem permanente, que não lhe possa ser retirado em algum revés da sorte" ( $D e$ Beat. Vit. I, 12). No final do diálogo, chega à conclusão de que a verdadeira felicidade está em Deus ou, só é verdadeiramente feliz, quem possui a Deus. ${ }^{5}$

Assim sendo, a busca da felicidade do homem converte-se na procura ou busca de Deus, o único que pode dar-lhe consistência e estabilidade.

\section{2 - O problema de Deus: a busca de Deus no interior do homem}

Em As Confissões, Agostinho diz que jamais duvidou da existência de Deus, o problema é como e onde encontrá-Lo, ${ }^{6}$ pois mesmo quando andou por caminhos tortuosos, no maniqueísmo, por exemplo, acreditou em Deus, ainda que de forma confusa, ao transformá-Lo numa substância corpórea. Seu problema vital não se expressa na pergunta sobre o que procurar, mas como e onde devo procurar: "Então, como Vos hei de procurar, Senhor? Quando Vos procuro, meu Deus, busco a vida feliz [...] Como procurar então a vida feliz? Não a alcançarei enquanto não exclamar: 'Basta, ei-la'! Mas onde poderei dizer estas palavras? Como procurar essa felicidade?” (Conf. X, 20).

Ainda em As Confissões, livro X, depois de um belíssimo diálego com a natureza, onde procura e não encontra Deus no mundo exterior, Agostinho chega à conclusão de que Deus, ou a verdade, habita no interior do homem e diz: "Tarde Vos amei, ó Beleza tão antiga e tão nova, tarde Vos amei! Eis que habitáveis dentro de mim e eu lá fora a procurar-Vos! Disforme, lançava-me sobre estas formosuras que criastes. Estáveis comigo e eu não estava convosco!" (Conf. X, 27 ).

Ao rever a atitude de inquietação e angústia que dominou toda sua vida, dáse conta de que, na realidade, nunca desejou outra coisa senão a verdade e que a verdade é o próprio Deus e que Deus se encontra no interior do homem, na sua alma. Logo, esta inquietação não é, senão, a ânsia por conhecer a si mesmo e a Deus.

5 Mais tarde, em A Cidade de Deus, Agostinho confirmaria a idéia de que o único e verdadeiro bem imutável é Deus: "Dizemos existir apenas um bem imutável, Deus, uno, verdadeiro e fẹ́liz" (XII, 1). O mesmo seria dito em As Confissōes: "A vida feliz consiste em nos alegrarmos em Vós, de Vós e por Vós. Eis a vida feliz, e não há outra" $(\mathrm{X}, 22)$.

6 Em As Confissōes, Agostinho diz: "Sempre acreditei que existieis e cuidáveis de nós, não obstante ignorar o que devia pensar de Vossa substância, ou que caminho nos levaria ou conduziria a Vós" (VI, 5). 
Por isso, em um outro diálogo filosófico, Solilóquios, escrito no retiro de Cassicíaco, depois de uma longa e belíssima oração a Deus, assim inicia o diálogo consigo mesmo, ou seja, com a razão:

"A - Eis que já orei a Deus.

$\mathrm{R}$ - Pois bem, o que queres saber?

A - Tudo o que acabo de pedir em minha oração.

$\mathrm{R}$ - Resume isso brevemente.

A - Desejo conhecer a Deus e à alma.

$R$ - E nada mais?

A - Nada mais absolutamente!" (Sol. II, 2,7).

Deus e a alma não constituem duas investigações separadas. Com efeito, Deus está na alma e revela-se na sua interioridade. Procurar Deus significa procurar a alma e procurar a alma significa reclinar-se sobre si mesmo, reconhecer-se na própria natureza espiritual e confessar-se: "Senhor, tu estavas, certamente, dentro de mim, mas eu me tinha afastado de mim mesmo e não me encontrava. Quanto mais a ti?" (Conf. V, 2). E recomenda: "Não saias de ti, mas volta para dentro de ti mesmo, a verdade habita no coração do homem" (De Vera Rel. VI, 39, 72).

Em diversas obras, Agostinho insiste na necessidade que tem o homem de desprender-se das coisas materiais, ligadas aos sentidos corporais, e conhecer-se a si mesmo, no fundo de sua alma, como meio para se chegar à verdade: "Viajam os homens para admirar a maravilhosa altura dos montes, a imensidão das ondas do mar, a vertiginosa corrente dos rios, a interminável latitude dos oceanos e o prodigioso curso dos astros e se esquecem do muito que há de admirar-se e de conhecer-se em si mesmo" (Conf. X, 8), e ainda: "Quantas riquezas atesoura o homem em seu interior! Mas de que lhe servem, se não se sondam e se investigam?" (In Ps. 76, 9).

Nesse sentido, a procura do homem, por si mesmo, é a procura de Deus; só no seu interior o homem pode encontrar Deus e só em Deus o homem encontra a sua "verdadeira felicidade", pois que só em Deus o homem procura e encontra; só Deus é a sua possibilidade.

\section{3 - A reviravolta antropológica: por uma "filosofia cristã"}

Agostinho renova a especulação filosófica sobre o homem, ao transformar o princípio filosófico-natural de Sócrates "Conhece-te a ti mesmo" em um princípio filosófico-religioso: "Oue eu me conheça e que te conheça, Senhor!" (Sol. II, 1,1).

Ao transformar o princípio filosófico-natural em princípio filosófico-religioso, introduz um importante elemento para a compreensão de sua especulação filosófica racional: a fé revelada, que daria um caráter original ao seu pensamento filosófico, que se caracterizaria por uma "filosofia cristã".

$\mathrm{Na}$ antropologia filosófica agostiniana, a fé é a condição da procura que não teria guia nem direção sem ela. A fé é início e término da procura. A procura encontra o fundamento e o guia na fé e a fé encontra sua consolidação na procura. 
Em O livre arbitrio, outra obra escrita ainda no espírito de Cassicíaco, mostra que a primeira condição para se compreender a verdade é a fé: "De fato, se não fosse uma coisa acreditar [por testemunho] e outra inteleccionar, e se não se devesse primeiro acreditar [por testemunho] nas verdades superiores e divinas que aspiramos a inteleccionar, sem razão teria dito o profeta: se não acreditares, não entendereis [...] Efetivamente, nem se pode dizer ter encontrado aquilo em que se acredita, mas é desconhecido [por intelecção], nem alguém se torna capaz de conhecer a Deus, se antes não acreditar [por testemunho] no que depois há de conhecer [por intelecção]" (De Lib. Arb. II, 2, 6).

Como se vê, Agostinho faz uma perfeita conciliação entre a fé (primeira condição para alcançar a Deus) e a razão ou filosofia, chegando à sua máxima de "Crede ut intellegas, intellege ut credas", ou seja: "Crê para que a fé ajude o intelecto a entender; entender, para que o intelecto procure a fé" (De Lib. Arb. II, 2, 6). Esta união perfeita entre fé e razão levaria o comentador Peter Brown a afirmar: "De fato, toda filosofia de Agostinho é filosofia cristã, desenvolvendo-se no âmbito da fé, não sendo senão esforço para reencontrar, pela razão, a verdade recebida por via da autoridade. Todos reconhecem que a necessidade de 'crer para compreender' é exigência essencial do agostinianismo, completada pelo 'compreender para melhor crer"'?

Mais do que vincular fé e razão, nivelando-as a um único plano - de uma "filosofia cristã" - Agostinho transforma o problema do homem, que não deixa de ser o problema do homem Agostinho, no problema da filosofia como um todo: a busca da felicidade. Tal façanha levaria Hylton Rocha a dizer que "para Agostinho, o objetivo da filosofia será sempre a procura da felicidade". ${ }^{8} \mathrm{O}$ próprio Agostinho, ao analisar a importância dos filósofos, especialmente Platão, na busca da felicidade, faz uma íntima relação entre filosofia e a felicidade do homem: "Que o filósofo tenha amor a Deus, pois se a felicidade é o fim da filosofia, gozar de Deus é ser feliz" (De Civ. Dei VIII, 9).

Para ele o filósofo procura a verdade, não simplesmente para ser sábio, mas para ser feliz, e coloca tal felicidade onde realmente ela se encontra, a saber, "na posse de um bem imutável [...] a verdade - Deus" (De Civ. Dei VIII, 9). Por isso, quem procura a felicidade busca a Deus e só ao encontrar a Deus encontrará a felicidade.

Assim, tentando responder aos questionamentos sobre onde encontrar a felicidade ou como pode o homem ser feliz, não tem dúvidas de que uma só é a resposta: a sabedoria. "Sabedoria, entretanto, que é a posse do conhecimento, de verdade tal, capaz de saciar plenamente a aspiração humana pela beatitude. $\mathrm{E}$ proclama ele, com convicção, ser a Sabedoria um dos nomes de Deus, mais precisamente, o nome de Cristo, o Filho de Deus". ${ }^{9}$ Em $A$ vida feliz, deixa bem claro esta afirmativa ao dizer: "Justamente aprendemos pela autoridade divina que 0

7 BROWN, Peter. La Vie de Saint Augustin. Trad. Jeanne Henri Marrou. Paris: Éditions du Seuil, 1971, 537 p. 109.

8 ROCHA, Hylton M. Pelos Caminhos de Santo Agostinho. São Paulo: Loyola, 1989, 269 p. 51.

9 GILSON, Étienne. Introduction a L'Étude de Saint Augustin. 3 ed. Paris: Librairie Philosophique J. Vrin, 1949, 370 p. 01 
Filho de Deus é precisamente a Sabedoria de Deus (1Cor 1,24); e o Filho de Deus, evidentemente, é Deus. Por conseguinte, é feliz quem possui a Deus [...] Mas, na vossa opinião, qual há de ser a Sabedoria senão a Verdade? Com efeito, também está dito: 'Eu sou a Verdade (Jo 14,6)" (De Beat. Vita, IV, 34).10

É interessante como Agostinho vincula sabedoria, posse do conhecimento ou da verdade, com a felicidade. Para ele não é possível a felicidade sem a verdade e vice-versa. A contemplação da verdade é condição sine qua non da beatitude. E a posse da verdade é inseparável da alegria beatificante. Comentando tal vinculaÇão, Étienne Gilson nos diz: "É fato capital para compreensão do agostianismo que a Sabedoria, objeto da filosofia, tenha se confundido sempre para Agostinho com a beatitude ou felicidade. O que ele procura é um bem tal que sua posse satisfaça todo desejo e, portanto, em conseqüência, que traga a paz". ${ }^{11}$ Para 0 mesmo comentador, aqui reside a chave do eudemonismo antropológico de Santo Agostinho, ao transformar o problema da filosofia e do homem em um só problema: a busca da felicidade.

\section{4- O problema do conhecimento: a busca da verdade}

Mas, apesar de considerar a fé como condição primeira para se chegar a Deus, dá capital importância à razão no processo do conhecimento da verdade de Deus. Tanto é assim que, em O livre arbítrio, Livro II, que traz como subtítulo "A existência de Deus", tentando refutar as palavras do cético: "não há Deus" (Sl. $53,1),{ }^{12}$ começa por procurar uma verdade racional segura (evidente) para dai chegar à uma certeza maior - Deus. Esta primeira verdade é que o homem existe, vive e pensa. Vejamos como chega a esta verdade primeira:

"A - Assim, pois, e para partirmos de verdades evidentes, pergunto-te, antes de mais, se tu existes. Ou receias porventura enganar-te a respeito desta pergunta, quando, se não existisses, de modo nenhum poderias enganar?

E - Passa já a outras considerações.

A - Por conseguinte, sendo evidente que existes, e que isso não seria para ti evidente de outra maneira, se não vivesses, também é evidente isto que tu vives. Inteleccionas que estas duas realidades são evidentíssimas?

10 Encontramos também tal identificação em A Trindade, quando diz: "E, portanto, o Pai é sabedoria, o Filho é sabedoria, o Espirito Santo é sabedoria, mas não são três sabedorias, e sim uma só sabedoria, porque neles o ser se identifica com o saber e o Pai, o Filho e o Espirito Santo são uma só essência" (VII, 3,6).

11 GILSON, Etienne. op. cit. 1949, p. 01.

12 A colocação do problema encontra-se nos seguintes termos: "Pois bem, supōe que algum daqueles insensatos de que está escrito - disse o insensato no seu coração: não há Deus (Sl. 53,1$)$ - te dissesse isto mesmo. Supõe que ele não estivesse resolvido a assentir contigo [por testemunho] ao que tu assentes, mas sim a saber se era verdade o que admites. Abandonarias esse homem, ou acharias que era teu dever convencê-lo por meio da razão?” (De Liv. Arb. V, 5). Em A Verdadeira Religiāo, Agostinho ressaltando a importância da argumentação racional para entendimento da fé, diz: "Deus emprega dois meios: a autoridade e a razão. A autoridade exige a fé e prepara o homem para a reflexão. A razão conduz à compreensão e ao conhecimento. A autoridade, porém, jamais caminha totalmente desprovida da razão, ao considerar Aquele em quem deve crer. Certamente, a suma autoridade será verdade conhecida com evidência" (IV, 24,45). 
E - Intelecciono perfeitamente.

A - Logo, é também evidente esta terceira realidade, a saber - que tu inteleccionas.

E- É evidente.

A - Qual de entre essas três realidades se te afigura prevalecer?

E - A inteligência [...]" (II, 3,7). ${ }^{13}$

O diálogo continua e a partir dessas três verdades seguras Agostinho chega à certeza da existência de Deus.

Segundo Philotheus Boehner e Étienne Gilson, "estamos aqui em face de um acontecimento singular na história da filosofia. É pela primeira vez que nos deparamos com uma prova da existência de Deus baseada na mais evidente das verdades, a saber, na existência da consciência conhecente. Não só isso, Agostinho funda a evidência desta verdade na existência do próprio sujeito que duvida, abalando assim o ceticismo pela raiz, isto é, pelo mesmo ato que lhe serve de fundamento". ${ }^{14}$

Tendo chegado à certeza de três verdades seguras, a saber: que ele existe, vive e pensa (e, entre estas três verdades, dado primazia à última, visto que, pelo pensamento, o sujeito pensante sabe que vive e existe, pois não poderia pensar sem viver e nem viver sem existir) Agostinho constrói uma teoria do conhecimento humano apresentando três níveis, organizados hierarquicamente, correspondentes às três verdades primárias: conhecimento sensivel (existir); sensação (viver) e ciência ou razão (pensar).

\section{1 - O conhecimento sensivel e a sensação}

A primeira preocupação de Agostinho é destacar a diferença entre os objetos sensíveis ou corpóreos e o conhecimento produzido sobre eles - a sensação. Os objetos corpóreos são atingidos pela sensação, da qual eles são a causa, mas eles, em si mesmos, são incapazes de sensação, ou de produzir conhecimento. Os objetos corpóreos estão no nivel do existir, ou exterior; a sensação, ao contrário, no nível do viver, é interior, produzida na alma. Ou seja, o processo do conhecimento humano parte do interior para o exterior. Não são os objetos que produzem conhecimento no homem, mas o homem que sensoria os objetos.

Apesar de afirmar que a sensação é própria da alma, diz que esta necessita do corpo (sentidos corpóreos) para se manifestar. Entretanto, longe de ser algo ativo, o corpo é passivo, é apenas um veículo, um meio utilizado pela alma para realização da sensação. A alma, ao contrário, é algo ativo, que se utiliza do corpo para produzir sensação (conhecimento): "Está claro, pois, que já não é o corpo que atua

13 Encontramos a mesma estrutura de raciocínio em A Trindade, quando Agostinho diz: "Quem, porém, pode duvidar que a alma vive, recorda, entende, quer, pensa, sabe e julga? Pois, mesmo se duvida, vive; se duvida lembra-se do motivo de sua dúvida; se duvida, entende que duvida, se duvida, quer estar certo; se duvida, pensa, sabe que não sabe; se duvida, julga que não deve consentir temerariamente. Ainda que duvide de outras coisas năo deve duvidar de sua dúvida. Visto que se não existisse, seria impossível duvidar de alguma coisa" (X, 10,14)

14 BOEHNER, Philotheus; GILSON, Étienne. História da Filosofia Cristã: desde as origens até Nicolau de Cusa. $2^{\mathrm{a}}$ ed. Trad. e not. Raimundo Vier. Petrópolis: Vozes, 1982, 582 p. 154. 
sobre a alma, e sim a alma sobre o corpo. Considerada em si mesma, a alma reside nos órgãos corporais, está presente neles, e de certo modo está de sentinela neles [...] Longe de se manter passiva, a alma é eminentemente ativa, pois é ela que dirige sua atenção aos respectivos órgãos corporais; é ela que vê, que cheira, que prova". 15

Os 'sentidos corpóreos, os olhos, por exemplo, neste caso, estão no nível do existir, assim como uma pedra, que em si mesma não cria conhecimento: "Com efeito, uma coisa é o sentido pelo qual o animal vê, e outra o sentido pelo qual, ao ver, evita ou busca as coisas que sensoria. O primeiro sentido encontra-se nos olhos; o segundo, internamente, na sensividade" (De Lib. Arb. II, 3,9). Fica claro, portanto, que no processo do conhecimento existem três realidades: o objeto, os sentidos (meio) e a sensação. ${ }^{16}$

Logo, para Agostinho, o que na filosofia moderna (no empirismo) chamamos de conhecimento sensivel, produzido pelos sentidos corpóreos, a rigor, não é conhecimento. O primeiro nível do conhecimento propriamente dito é a sensação, produzida pelo sentido interior - a alma. O corpo, apesar de recessário, é apenas um instrumento.

Tal posicionamento levaria Agostinho a reconhecer que, embora o homem participe da perfeição do Ser através de sua alma, considerada um bem superior, nem por isso o corpo, considerado como parte inferior, deixa de fazer parte da natureza humana. Pois, mesmo que a alma seja superior (substância espiritual), ela necessita de um corpo para com ele formar uma substância completa: o homem. Neste sentido, o corpo não é mero acidente; ele faz parte, também, da natureza do homem; "com efeito, o corpo não é apenas ornamento do homem, adjuntório exterior; faz parte de sua natureza" (De Civ. Dei I, 8). Em função dessa necessidade de complementaridade entre alma e corpo, embora não superando o dualismo entre parte superior e inferior, diz que não podemos denominar o homem nem só pela alma, nem só pelo corpo: "É grande verdade não ser todo o homem a alma do homem, mas sua parte superior, nem seu corpo todo o homem, mas sua parte inferior" (Idem XIII, 24).

Assim sendo, Agostinho fala da existência de duas luzes no homem: uma corporal, própria dos sentidos externos, e outra espiritual, própria do sentido interno, ou da alma, que capacita a corporal a ver os objetos. Portanto, se o cego não vê, isso se deve ao fato de carecer do órgão corporal indispensável. Mas nem por isso lhe falta a luz interior, que o capacitaria a ver, se dispusesse do órgão complementar.

15 BOEHNER, Philotheus; GLLSON, Étienne. op. cit. p. 160.

16 Em o Solilóquios, Agostinho faz esta distinçăo da seguinte forma: "Com efeito, não é a mesma coisa ter olhos e olhar, assim como olhar não é o mesmo que ver. A alma necessita pois destas três condições: ter olhos para bem se servir deles; olhar e ver" (II, 6,12). O mesmo aparece em $A$ Trindade, quando diz: "Por conseguinte, as três realidades: o objeto visto, a própria visão e a atenção do espírito que enlaça uma coisa a outra, são bem fáceis de serem distinguidas, tanto pela peculiaridade de cada um, como pela diferença de suas naturezas" (XI, 2,2). 
Apesar de não ser um mal em si, ${ }^{17} \mathrm{o}$ corpo tem o poder de ofuscar a alma, ou de a iludir com suas percepções sensiveis (falso conhecimento): "Ó alma, olha se podes. Oprimida que estás pelo peso do corpo sujeito à corrupção e curvada sob múltiplos e variados pensamentos terrenos. Olha bem, e compreende, se podes: Deus é a verdade! $(S b$ 9,15). Mas não, não podes, pois resvalas para os pensamentos terrenos e rotineiros. Qual é, pois, eu te peço, esse peso que te faz recair, senão o das impurezas contraídas pelo vigo das paixões e erros de tua peregrinação" (De Trin. VIII, 2,3). Por isso, enquanto a alma se deixar levar pelos sentidos externos não atingirá o nivel da razão; é preciso transcender os sentidos corpóreos e atingir o mundo da ciência, ou das verdades universais: "Todavia, a não ser que o ultrapasse, o que nos é transmitido pelos sentidos do corpo não pode chegar à ciência" (De Lib. Arb. II, 3,9). ${ }^{18}$

Além disso, Agostinho acreditava que o homem (corpo e alma) é um ser individual, ${ }^{19}$ o que resulta serem as duas luzes (dos sentidos externos, enquanto meio ou instrumento, e do sentido interno - a alma) diferentes para cada indivíduo, pois se assim não fosse, pelos sentidos externos, os olhos, por exemplo, "eu não poderia ver pelos meus olhos o que tu não visses [...] Por este fato é evidente que os teus sentidos são apenas teus, e os meus, apenas meus" (De Lib. Arb. II, 7,15). Da mesma forma, acontece quanto ao sentido interior: a sensação de sabor provocada por um mesmo alimento, por exemplo, não causa a mesma sensação em duas pessoas. Disso se segue que, sendo os sentidos externos e o interno particularizados, não podemos chegar às verdades universais através deles, mas só a conceitos particulares.

\section{2 - A sensação e a razão}

Em O livre arbitrio, Agostinho tem certeza de que o sentido interior, pelo qual sensoriamos os objetos, é superior aos objetos sensiveis, incluindo aí os sentidos corpóreos. Entretanto, apesar de ser superior, o sentido interior ainda não é a razão, visto que até os animais o possuem: "Com efeito, uma coisa é o sentido [externo] pelo qual o animal vê, e outra o sentido [interno] pelo qual, ao ver, evita

17 Em diversas de suas obras, e em diversos momentos, Agostinho insiste em afirmar que "nenhuma natureza, absolutamente falando, é um mal" (De Civ. Dei X I,22).

Esta mesma idéia reaparece em A Trindade, onde Agostinho prega a necessidade de passarmos das coisas materiais às espirituais, ou das coisas baixas às elevadas: "Assim como o corpo tem possibilidade natural, por estar ereto, de olhar para os corpos colocados nas maiores alturas, isto é, para os do céu; do mesmo modo a alma, substância espiritual, deve alevar-se ao mais sublime da ordem espiritual, inspirada não pela soberba, mas por um amor piedoso e justo" (XII, 2,2) e em $A$ Verdadeira Religiāo, onde fala da passagem do "homem velho: exterior e terreno" ao "homem novo: interior e espiritual" (Cf. II, 26, 48-49). Já em o Solilóquios, Agostinho prega uma dupla purificação do homem: do corpo (ascese) e da alma (morai), como meio para se alcançar a verdade. Do corpo, ou da saúde do corpo, porque, como vimos, este é instrumento para que a alma sensorie os objetos, e a alma precisa dele para reconhecer na natureza a beleza de Deus. $\mathrm{E}$ da alma, para poder alcançar as verdades etemas (Cf. Sol. III, 9, 16-26).

19 Seguindo as Sagradas Escrituras, Agostinho nāo tem dúvidas de que, no início, Deus fez apenas um homem: "quanto ao homem, chamado, por criação, natural, a ocupar lugar entre os anjos e os seres irracionais, Deus criou apenas um" (De Civ. Dei XI, 21) e lhe deu uma alma; "Deus fez o homem à sua imagem e deu-lhe alma ..." (Idem XII, 23). 
ou busca as coisas que sensoria. O primeiro sentido encontra-se nos olhos; o segundo, internamente na sensividade. Por meio deste segundo, os animais ou buscam e șe apossam do prazer que sentem, ou evitam e repelem pela dor que experimentam, não só os objetos que vêem, mas também os que são captados pelos demais sentidos do corpo [...] Como disse, não podemos a este mesmo chamar-lhe razão, pois é evidente que este até nos animais existe (De Lib. Arb. II, 3,8).

Ainda em O livre arbítrio, referindo-se ao sentido interior, pergunta:

"A - Não será ele [ a alma ] a mesma razão, de que os animais carecem?

E - Eu penso antes que por meio da razão, nós percebemos que existe certo sentido interior, ao qual, pelos bem conhecidos cinco sentidos, são comunicados todos os objetos sensoriados [...] Conhecendo por meio da razão este outro, como disse, não podemos a este mesmo chamar-lhe de razão" (II, 3, 8). ${ }^{20}$

Deste modo, Agostinho dá-nos notícia de um terceiro sentido, infinitamente superior, chamado razão: "São evidentes os dados seguintes: pelos sentidos externos sensoriam-se os objetos corpóreos; esses mesmos sentidos não podem ser sensoriados pelos próprios sentidos; pelo sentido interior, porém, sensoriam-se não apenas os objetos corpóreos por meio dos sentidos externos, mas também os mesmos sentidos externos; finalmente, pela razão, ela mesma e todos esses dados são conhecidos, ficando incluidos na ciência" (Idem II, 4,10). Logo, conclui: "É inegável, com efeito, que não só temos corpo, mas também certa vida [...] fenômenos que verificamos também nos animais. Temos, além disso, um terceiro princípio, por assim dizer cabeça ou vistá da nossa alma, ou o que mais adequadamente se possa aplicar à nossa razão ou inteligência" (Idem II, 6,13).

Portanto, para Agostinho, esta terceira verdade: razão (pensar), não só é diferente das outras duas, mas é a mais importante, pois é através dela que o sujeito pensante sabe que existe e vive. Esta terceira verdade só o homem a possui: "Assentamos igualmente que das três realidades é prevalente a que só o homem possui além das outras duas, ou seja, a de inteleccionar" (Idem II, 6,13) ${ }^{21}$

20 Também em A Trindade, Agostinho tem essa certeza ao dizer: "Quando a essa parte de nosso ser que se ocupa da ação das coisas temporais e corporais e que não nos é comum com os animais, certamente relaciona-se com a razão" (De Trin. XII, 2,3)

21

O mesmo seria dito em $A$ Cidade de Deus: "Deus fez o homem à sua imagem e deu-lhe alma, dotada de razão e inteligência, que o tomava superior a todos os restantes animais terrestres, nadadores e voadores, destituidos de mente" (XII, 23). Já em A Trindade, Agostinho chega à mesma certeza, porém, troca a palavra inteleccionar por entender: "Ninguém duvida que aquele que entende está vivo; e aquele que está vivo é porque existe. Portanto, o ser que entende existe e vive, o que não acontece com o cadáver que não vive. Nem acontece com a alma dos animais, que vive, mas não entende. A alma humana, porém, vive, entende e existe, de modo peculiar e mais nobre" (X, 10, 13). Igualmente em A Verdadeira Religiảo, Agostinho diz: "Ninguém contesta que os animais irracionais vivem e sentem. Do mesmo modo é aceito ser superior a eles a alma humana. Näo pelo fato de ela perceber o sensivel, mas pelo poder que ele tem de julgar. Com efeito, são encontrados muitos animais cuja vista é mais penetrante que a dos homens. Mas para levantar um julgamento sobre isso, nāo é possivel a vida exclusivamente sensivel. É preciso possuir razão. O que está ausente nos animais é o que faz a nossa superioridade. O ser que julga é superior à coisa julgada - isso é facílimo de se constatar. Além do mais, o ser racional não julga somente a respeito dos objetos sensiveis, mas também sobre seus próprios sentidos" (V, 29,53). 
Diferente dos conhecimentos produzidos pelos sentidos externos e interior, que são individualizados, defende que as verdades racionais são comuns e acessíveis a todos. Pois, "se existe a idéia de uma sabedoria que tu podes ver e que eu o saiba, e que eu posso ver sem que tu o saibas, e que por isso não podemos mostrar um ao outro, e contudo é idêntica em todos, é mister admitir que tal idéia nos seja igualmente acessivel a todos" (De Lib. Arb. 10,28). E cita como exemplo de verdades racionais a essência do número matemático, que "está presente a todos os que são dotados de razão, de modo que todos os que pretendem fazer contas se esforçam por aprendê-la, cada um pela própria razão e intelecto. Uns conseguem mais facilmente, outros mais dificilmente; outros de modo nenhum, embora essa verdade se mostre igualmente a todos os que são capazes de a captar" (Idem, II, $8,20)$. Tais verdades são transcendentais, pois não pertencem a nenhuma alma em particular e em todos se fazem presentes.

\section{3 - A razão e a verdade}

Agostinho fala da razão como um terceiro princípio, ou sentido, pelo qual o sentido interior julga todas as coisas: "Temos outro sentido, [...] sentido infinitamente superior, pelo qual sentimos o justo e o injusto, o justo por uma espécie inteligivel, o injusto pela privação de tal espécie" (De Civ. Dei XI 27,2).

Mas a razão ainda não é a verdade. A razão é o olho, ou o sol que ilumina a alma para ver e julgar as coisas: "A razão é o olhar da alma" (Sol. II, 6,13).

A razão é o meio ou a mediadora entre o nosso sentido interior (a alma) e as verdades eternas, imutáveis e universais, pois sendo os seres humanos mutáveis e contingentes não podem conhecer por um contato direto as verdades eternas, mas só por mediações, por "leis" ou "normas" racionais, frutos da iluminação divina. Agostinho apresenta como exemplo de leis ou normas racionais pertencentes ao mundo das verdades eternas os modelos ideais da matemática, da estética e da ética. Não que os conteúdos destes ideais pertençam ao mundo das verdades eternas, ou que sejam verdades em si mesmos, mas apenas suas leis ou normas, segundo as quais a razão julga todas as coisas. Assim sendo, quando julgamos uma coisa quadrada, ou igual, ou semelhante, por exemplo, "é segundo a lei da quadratura que se julgará uma praça quadrada, uma pedra quadrada, um quadro e uma jóia quadrada; é segundo toda lei da igualdade que se julgará harmonioso o caminhar de uma formiga, bem como o caminhar de um elefante [...] uma vez que esta lei de todas as artes é absolutamente imutável [...] parece suficientemente que há, acima de nossa alma, uma lei a que se chama verdade" (De Vera Rel. 30, 56). Estas verdades eternas, imutáveis e universais estão presentes em todos os homens, não como reminiscência, ou recordação, segundo Platão, mas por iluminação divina, emanação ou participação na mente do homem.

Para ele, a alma conhece as verdades eternas por iluminação divina, mediante uma luz interior, "a verdadeira luz, aquela que ilumina todo o homem vindo a este mundo" (De Trin. XII, 24) e pela qual a razão toma consciência da presença de Deus: "Vários são os dotados de vista mais aguda que a nossa, para ver a luz 
sensivel, mas não podem atingir a luz incorpórea, cujos raios iluminam a alma [...] E a medida de nossa participação nessa luz é a medida de nossa inteligência" (De Civ. Dei XI, 27). ${ }^{22}$

Portanto, se a razão é superior à alma, a lei que lhe dá suporte é maior ainda e esta lei é a Lei divina: "É incontestável que aquela natureza imutável que se acha acima da alma racional é Deus [...] Assim sendo, a alma toma consciência de que não é por si mesma que pode julgar sobre a forma e o movimento dos corpos. Ao mesmo tempo, ela reconhece que sua própria natureza é superior à natureza daquelas coisas sobre as quais julga. Contudo, reconhece também ser ela mesma de natureza inferior àquela de quem recebe o poder de julgar. $E$ que não é capaz de julgar sobre essa natureza que lhe é superior" (De Vera Rel. VI, 31, 57). ${ }^{23}$

Sendo a razão a intermediária entre as verdades eternas e a alma, e estando esta diretamente ligada ao mundo sensível, pois utiliza-se dos sentidos corporais, Agostinho chega a falar de duas razões no homem, ou melhor, é como se nossa razão estivesse dividida em duas partes. Uma parte é inferior, que cuida do mundo sensivel, que é a parte da alma ligada ao mundo sensivel. A esta parte, ou a atividade desta razão, dá o nome de ciência, que é a atividade da razão responsável pelas coisas temporais: "Prossigamos agora, com a ajuda do Senhor, o estudo já começado sobre a parte da razão com a qual a ciência se relaciona, isto é, com o conhecimento do temporal e do mutável, necessário", e ainda: "Ora, o apetite sensível é vizinho da razão que se aplica à ciência, visto que é sobre os próprios objetos temporais percebidos pelos sentidos do corpo que a ciência - dita ciência da ação - raciocina" (De Trin. XII 12,17). A outra é a parte superior, pela qual atingimos as coisas superiores: "Chegamos, agora, ao assunto que nos determinamos a considerar: a parte mais nobre da alma humana pela qual se conhece a Deus, ou se pode vir a conhecê-lo. Vamos procurar aí a imagem de Deus" (De Trin. XIV 8,11).

Há, portanto, duas funções da razão no homem: a razão da ação (da ciência) e a razão da contemplação (da verdade), mas é uma única razão: "Esta dissertação que nos levou a procurar na mente de todo homem uma espécie de matrimônio entre a razão da contemplação e a da ação, sem que essa distribuição de funções próprias de cada uma comprometesse a unidade da mente" (De Trin. XII, 12, 19).

Com esta divisão de funções, Agostinho faz uma distinção entre ciência e verdade. Estando a primeira contida na segunda, como diz o Apóstolo: " $A$ um, o Espínto dá a sabedoria; a outro, a ciência, segundo o mesmo Espirito" (1Cor 13,12): "Há diferença entre a contemplação dos bens eternos e a ação que nos permite fazer bom uso dos bens temporais [...] Por isso, considero que se deva estabelecer diferença entre 0 dom de falar com ciência e o dom de falar com sabe-

22 Igualmente em A Trindade, Agostinho fala por diversas vezes na idéia de participação, como: "Nossa iluminação é uma participação no Verbo, isto é, àquela vida que é a luz dos homens (IV, 2,4); "A Sabedoria é sábia e é sábia por si mesma. E toda alma torna-se sábia pela participação na sabedoria" (VI, 1,2) e ainda: "A alma não será sábia por suas próprias luzes, mas por participação daquela luz suprema onde reinará eternamente e será feliz" (XIV, 12,15).

23

O mesmo encontramos em A Trindade: "Se procurarmos o que possa existir de superior a essa natureza racional, e se investigarmos a verdade, encontraremos que essa verdade é Deus" (XV 1, 1). 
doria" (De Trin. XII 14, 22 e 25), e conclui: “A sabedoria é o conhecimento intelectivo das realidades eternas; e a ciência, o conhecimento racional das coisas temporais. E a primeira, sem nenhuma dúvida, tem a preferência" (De Trin. 15,24).

Dentro da mesma linha de raciocínio, faz uma distinção entre ser "douto" e ser "sábio", ou entre a sabedoria do homem (ciência) e a sabedoria de Deus (verdade). E citando o caso de Pitágoras, diz: "Este, não ousando intitular-se sábio, preferiu dizer-se filósofo, ou seja, amante da sabedoria" (De Trin. XIV 1,1).

Por isso, fugindo de uma visão panteísta, Agostinho diz que a verdade (Deus) é, ao mesmo tempo, interior, por estar presente na nossa mente (na alma), e transcendente, por ser universal, pois está presente em todos os homens e não pertence a nenhum em particular. Daí nos recomenda: "Não saias de ti, mas volta para dentro de ti mesmo, a Verdade habita no coração do homem. E se não encontras senão a tua natureza sujeita a mudanças, vai além de ti mesmo. Em te ultrapassando, porém, não te esqueças que transcendes tua alma que raciocina. Portanto, dirige-te à fonte da própria luz da razão" (De Vera Rel. VI, 39, 72).

Sendo a verdade ao mesmo tempo imanente e transcendente ao homem, prega, mais uma vez, a necessidade de uma purificação da alma como meio de participar do mundo das verdades eternas - Deus: "Faz-se mister, por isso, purificar nossa mente para podermos contemplar inefavelmente o inefável" (De Trin. I,1,3). E para tal, otimisticamente, conta com dois elementos: a fé revelada: "Não conseguindo ainda essa purificação, alimentamo-nos da fé, conduzidos por caminhos mais praticáveis a fim de sermos capazes de chegarmos a compreender a Deus" (Idem, I, 1,3) e a graça divina, pois, dadas nossas fraquezas humanas, por si só o homem não tem forças para alcançar a Deus. Temos que contar com a graça redentora de Deus, encarnada no seu Filho, o Mediador, Cristo: "A alma não será sábia por suas próprias luzes, mas por participação daquela luz suprema onde reinará eternamente e será feliz" (De Trin. XIV 12,15).

Agostinho critica aqueles que pensam que por conta própria, ou simplesmente pela via da razão prática, podem alcançar a Deus: "Há alguns que julgam poder alcançar a purificação, unir-se a Deus pelas próprias forças e assim chegar à contemplação de Deus. Esses mancham-se sumamente pela própria soberba" (De Trin. IV, 15,20), e aponta dentre estes os filósofos, inclusive os platônicos, como, por exemplo, em As Confissões, quando ao comparar a arrogância dos livros platônicos com a humildade proposta pelas cartas paulinas, diz: "Neles não se aprende o segredo da piedade cristã, nem as lágrimas da confissão, nem o sacrifício de um coração contrito e humilde, nem muito menos a ainda a graça desse cálice santíssimo que encerra o preço de nossa redenção [...] Nos livros platônicos ninguém ouve Aquele que diz: 'Vinde a Mim vós que trabalhais'. desdenham em aprender d'Ele que é manso de coração: 'Escondestes estas coisas aos sábios e entendidos, e as revelastes aos humildes' (Mt 11,25)" (Conf. VII, 21). E referindo-se aos momentos em que esteve envolvido com eles diz: "Tagarelava à boca cheia como um sabichão, mas se não buscasse em Cristo Nosso Salvador o caminho para Vós, não seria perito mas perituro. Já então, cheio de meu castigo, começava a querer ser um sábio; não chorava e, por acréscimo, inchava-me com a ciência" (Conf. VII, 20). 
Também diz que para alcançar Deus é necessário transcender a razão, entregar-se gratuitamente na busca da face incompreensivel, ou inefável de Deus. É viver em Deus, embora ainda não o tendo plenamente. É seguir as palavras do Eclesiástico que diz: "Aqueles que me comem, terão mais fome; e os que me bebem, terão mais sede" (Eclo 24,29). E para que isto aconteça só há um caminho - a humildade cristã. Só os humildes de coração contemplarão a Deus ou a Verdade. No nível da razão os homens se contentarão com a ciência.

Portanto, concluindo, diríamos que para Agostinho o conhecimento humano se dá em três niveis: o conhecimento sensivel (existir), a sensação (viver) e a razão ou ciência (pensar). Além disso há um quarto grau que é a verdade. Mas esse foge ao domínio da razão humana. A verdade pertence a Deus, a ela o homem só contempla por iluminação mediante a ajuda da graça divina.

\section{Referências bibliográficas}

AgostinHo, Santo. A Cidade de Deus: contra os pagãos. 3. ed. Trad. Oscar Paes Leme. Petrópolis: Vozes; São Paulo: Federação Agostiniana Brasileira, 1991, v. I, 414; v. II, 589 p. (Coleção Pensamento Humano).

Cartas a Proba e a Juliana: direção espiritual. Trad. e not. Nair de Assis Oliveira, rev. E. Gracindo. São Paulo: Paulinas, 1987, 99 p. (Série Espiritualidade).

A Vida Feliz: diálogo filosófico. Trad. e not. Nair de Assis Oliveira, rev. H. Dalbosco. São Paulo: Paulinas, 1993,109 p. (Série Espiritualidade).

A Trindade. Trad. e int. Augustino Belmonte, rev. e not. Nair de Assis Oliveira. São Paulo:

Paulus, 1994,726 p. (Coleção Patristica).

Confissōes. 9. ed. Trad. J. Oliveira Santos e A. Ambrósio de Pina. Petrópolis: Vozes, 1988, 367

p. (Coleção Pensamento Humano).

O Livre Arbitrio. 2. ed. Trad. e not. Antonio Soares Pinheiro. Braga: Faculdade de Filosofia, 1990, $367 \mathrm{p}$.

Solilóquios. Trad. e not. Nair de Assis Oliveira. rev. H. Dalbosco. São Paulo: Paulinas, 1993, 162 p. (Série Espiritualidade).

A Verdadeira Religião. 2. ed. Trad. e not. Nair de Assis Oliveira, rev. Gilmar Corazza. São Paulo: Paulinas, 1987, 213 p. (Série Espiritualidade).

Comentários aos Salmos. Trad. H. Dalbosco. São Paulo: Paulus, 1997, vol. 1 - Salmos 1 a 50, 922 p., vol. 2 - Salmos 51 a 100, 1202 p. (Coleção Patristica n. 9)

A Doutrina Cristã: manual de exegesse e formação cristã. Trad. Nair de Assis Oliveira. São Paulo: Paulinas, 1991, 386p.

BOEHNER, Philotheus; GLSON, Etienne. História da Filosofia Cristã: desde as origens até Nicolau de

Cusa. 2. ed. Trad. Raimundo Vier. Petrópolis: Vozes, 1982, 582 p.

BROWN, Peter. La Vie de Saint Augustin. Trad. Jeane Henri Marrou. Paris: Éditions du Seuil, 1971, $537 \mathrm{p}$.

GLSON, Étienne. Introduction a L'Étude de Saint Augustin. 3. ed. Paris: Librairie philosophique J. Vrin, $1949,367 \mathrm{p}$.

RAMOS, Francisco Manfredo Tomás. A Idéia de Estado na Doutrina Ético-Politica de Santo Agostinho: um estudo do epistolário comparado com o 'De Civitate Dei'. São Paulo: Loyola, 1984, 370 p. (Coleção Fé e Realidade n. 15).

ROCHA, Hylton Miranda. Pelos Caminhos de Santo Agostinho. Săo Paulo: Loyola, 1989, 269 p. 